\title{
RELIGION IN ROMAN EGYPT
}



, R E L I G I O N I N ,

R O M A N E G Y P T

ASSIMILATION AND RESISTANCE

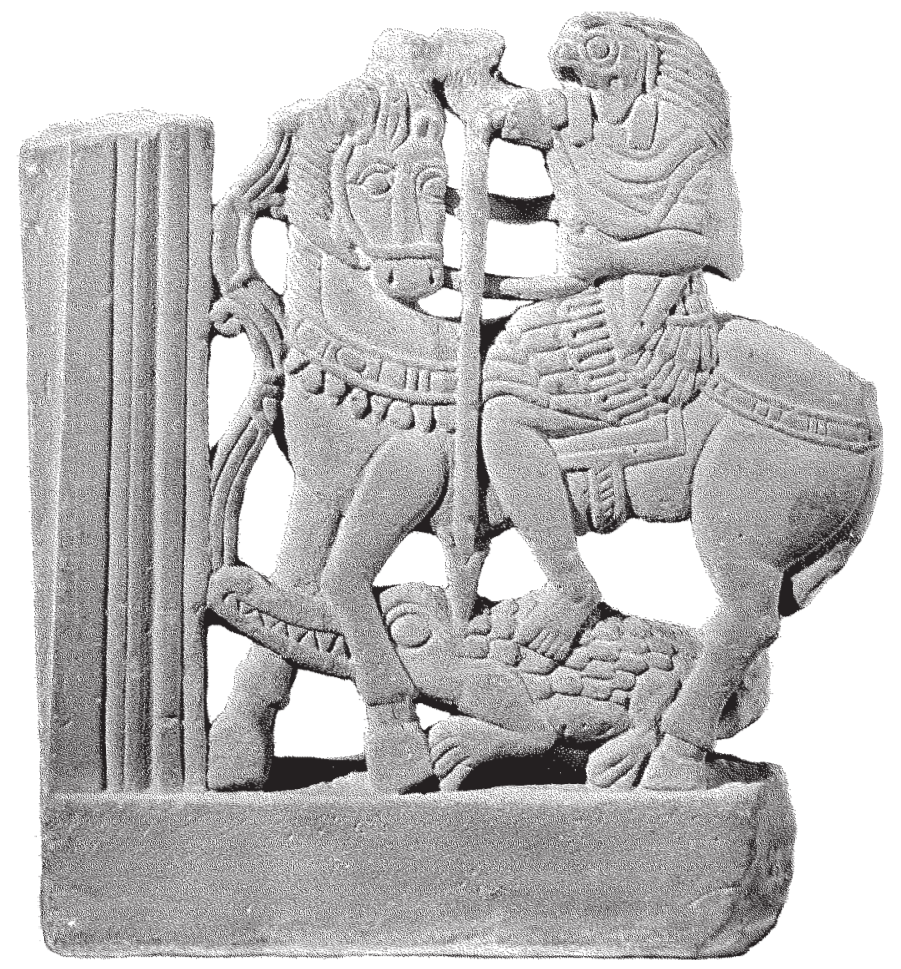

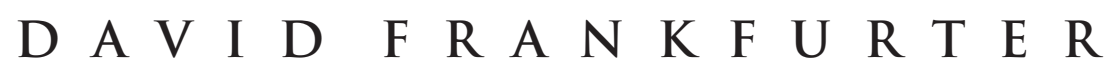

, PRINCETON UN IVERSITY PRESS,

P R I N C E T O N, N E W J E R S E Y 
COPYRIGHT @ 1998 BY PRINCETON UNIVERSITY PRESS

PUBLISHED BY PRINCETON UNIVERSITY PRESS, 41 WILLIAM STREET,

PRINCETON, NEW JERSEY 08540

IN THE UNITED KINGDOM: PRINCETON UNIVERSITY PRESS, CHICHESTER, WEST SUSSEX

ALL RIGHTS RESERVED

LIBRARY OF CONGRESS CATALOGING-IN-PUBLICATION DATA

FRANKFURTER, DAVID, 1961-

RELIGION IN ROMAN EGYPT : ASSIMILATION AND RESISTANCE / DAVID

FRANKFURTER.

P. CM.

INCLUDES BIBLIOGAPHICAL REFERENCES AND INDEX.

ISBN 0-691-02685-8 (CL : ALK. PAPER)

1. EGYPT-RELIGION-332 B.C.-640 A.D. 2. CHRISTIANITY AND OTHER

RELIGIONS-EGYPTIAN. I. TITLE.

BL2455.F73 1998

$200^{\prime} .932^{\prime} 09015-$ DC21 $97-49576 \quad$ CIP

THIS BOOK HAS BEEN COMPOSED IN SABON TYPEFACE

TITLE PAGE ILLUSTRATION: ARMORED, MOUNTED HORUS SPEARING CROCODILE. SANDSTONE. H: 49.1 CM. W: 32 CM. D: 7.8 CM. PARIS, LOUVRE E.4850. COURTESY OF THE LOUVRE.

PRINCETON UNIVERSITY PRESS BOOKS ARE PRINTED ON ACID-FREE PAPER AND MEET THE GUIDELINES

FOR PERMANENCE AND DURABILITY OF THE COMMITTEE ON PRODUCTION GUIDELINES FOR BOOK LONGEVITY OF THE COUNCIL ON LIBRARY RESOURCES

HTTP://PUP.PRINCETON.EDU

PRINTED IN THE UNITED STATES OF AMERICA

$\begin{array}{llllllllll}1 & 3 & 5 & 7 & 9 & 10 & 8 & 6 & 4 & 2\end{array}$ 
DEDICATED TO THE MEMOR Y O

\section{Alexander Moritz Frankfurter}

$1963-1993$

HOW COULD WE SING THELORD'S SONG

I N A F REIGN LAND?

- PS 137 
